\title{
Proximate Composition and Sensory Properties of Complementary Food Formulated From Malted Pre-Gelatinized Maize, Soybean and Carrot Flours
}

\author{
Patience C. Obinna-Echem ${ }^{1}$, Lucretia I. Barber ${ }^{1} \&$ Confidence I. Enyi $^{1}$ \\ ${ }^{1}$ Department of Food Science and Technology, Rivers State University, P.M.B 5080, Port Harcourt, Rivers State, \\ Nigeria \\ Correspondence: Patience C. Obinna-Echem, Department of Food Science and Technology, Rivers State \\ University, P.M.B 5080, Port Harcourt, Rivers State, Nigeria. E-mail: patience.obinna-echem@ ust.edu.ng
}

Received: November 25, 2017

Accepted: December 21, 2017 Online Published: January 25, 2018

doi:10.5539/jfr.v7n2p17

URL: https://doi.org/10.5539/jfr.v7n2p17

\begin{abstract}
The nutrient and sensory properties of malted pre-gelatinized maize supplemented with varying amounts of soy and carrot flour was evaluated. The blends (Malted pre-gelatinized maize flour : Soy flour : Carrot flour) in grams were: A (80: 20: 0), B (73.125: 23.125: 3.75), C (66.250: 26.250: 7.50), D (65.625: 23.125:11.25), E (65: 20:15), F (63.125: 33.125: 3.75), G (63.125:25.625: 11.25), H (60: 25: 15) and I (100:0:0). There were significant $(\mathrm{P} \leq 0.5)$ differences in the proximate composition of the blends. The moisture content ranged between $3.55-8.10 \%$. The protein content of the samples increased $(\mathrm{P} \leq 0.5)$ with the increase in soy substitution and varied from $11.61 \%$ for the control (sample I) to $21.53 \%$ for sample F. The fat, ash and crude fibre content of the blends varied from $1.68-10.86,1.45-2.8$ and $0.20-4.40 \%$ respectively. The control had significantly $(\mathrm{P} \leq 0.5)$ the highest carbohydrate content of $75.61 \%$, while it varied between 55.30 and $71.60 \%$ for others. The energy values varied from $360.43-405.00 \mathrm{Kcal} / \mathrm{g}$. The sensory scores were based on a 9-point hedonic scale, with 1 and 9 expressed as dislike extremely and like extremely. The assessors' likeness for the sensory attributes (colour, texture, taste, aroma and general acceptability) was below neither like nor dislike. This study revealed that substitution with soybeans and carrot flours increased the nutrient composition of the malted pre-gelatinized maize, soybean and carrot flour blends. Particularly the soy flour as sample $\mathrm{F}$ with the highest soy flour substitution (33. 123g) had significantly the highest protein (21.53\%), fat (10.86\%) and energy (405 $\mathrm{Kcal} / \mathrm{g}$ ) values. This would be recommended for good quality porridge. Although, the sensory analysis revealed the need for further investigation on processing methods especially the malting process as to enhance the overall acceptability of the product.
\end{abstract}

Keywords: complementary food, malted pre-gelatinized maize, carrot soybean flour, proximate composition, sensory analysis

\section{Introduction}

Majority of maize products in developing countries are for human consumption while in the developed world it is mainly used for industrial purposes and animal feed (FAO, 2012). Maize (Zea mays L., Poaceae) is the most important cereal in the world after wheat and rice with regard to cultivation areas and total production. It has an average chemical composition of $10.3 \%$ protein, $60.5 \%$ starch, $1.2 \%$ sugar, $2.5 \%$ crude fibre and other substances (Addo-Quaye, Darkwa \& Ampiah, 2011). It also contains high level of dietary fiber (12.19\%) but low in 'trace minerals and ascorbate (Hornick \& Weiss, 2011). Maize protein content varies in common varieties from about 8 to $11 \%$ of the kernel weight (FAO, 2014). The protein is relatively fair in the sulphur containing amino acids, methionine and cystine but low in lysine and very low in tryptophan (Okoh, 2014).

Maize is prepared and consumed in a variety of ways and its economic value is increased through the development of technologies which process it into value added products and thus promoting its production and consumption. Fermentation of maize has some advantages. It helps in the introduction of probiotic bacteria so by consuming fermented foods, beneficial bacteria and enzymes are being added to overall intestinal flora for important health benefits (Kalui, Mathara \& Kutima, 2010). The breakdown of some of the sugars and starches in food during fermentation makes for easy digestibility of fermented foods (Elyas, El Tinay, Yousif \& Elsheikh, 
2002; Lei, Friis \&Michaelsen, 2006). Other advantages of fermentation include the increase in availability of vitamins and minerals and the removal of some natural compounds that interfere with the absorption of nutrients (Towo, Matuschek \& Svanberg, 2006).

One of the principal ways of using maize is by fermenting it into ogi/akamu (a cereal gruel that is often used as complementary food). Maize starch is also used for products such as custard (vanilla flavoured corn starch) which is often given as complementary food to infants. The disadvantage of ogi is that the traditional production process has been implicated in nutrient losses (Obinna-Echem, Kuri \& Beal 2014). On the other hand, germination (malting or sproulting) is a simple and traditional method that can be used at home. It involves hydrating and holding the grains at ambient temperature to sprout. During germination, both endogenous and newly synthesized enzymes begin to modify seed constituents, starch, protein and fat are hydrolysied by amylolytic, proteolytic and lipolytic enzymes, respectively (Katina, Liukkonen, Kaukovirta-Norja, Adlercreutz, Heinonen, Lampi, Pihlava, \& Poutanen, 2007). This non-thermal process has the advantages of: reduction of anti-nutritional factors, including phenolic compounds, phytic acid, trypsin inhibitors and oligosaccharides (Shimelis \& Rakshit, 2007), enhancement of organoleptic qualities due to a softening of texture and an increase in the flavour of various cereals (Subba Rao \& Muralikrishna, 2002), improvement of the functional properties (water absorption, foaming and gelation) of rice flour (Moongngarm, Moontree, Deedpinrum, \& Padton, 2014), generation of bioactive components such as riboflavin, thiamine, biotin, pantothenic acid, niacin, vitamin C, tocopherols and phenolic compounds, and also increase their availability (Moongngarm \& Saetung, 2010) increase in the contents of free amino acids and the improvement of protein digestibility (Afify, El-Beltagi, Abd El-Salam \& Omran, 2012).

Soybean (Glycine max ) is a legume species native to East Asia, widely grown for its edible bean which has numerous uses (Anders, 2013). Soy beans have a relatively low content of carbohydrates and a relatively high content of proteins, and furthermore, contain a number of health promoting compounds. Together, soybean oil and protein content account for about $60 \%$ of the dry beans by weight (protein at $40 \%$ and oil at $20 \%$ ). The remainder consists of $35 \%$ carbohydrate and about $5 \%$ ash. Soybean consists of approximately $8 \%$ seed coat or hull, $90 \%$ cotyledons and 2\% hypocotyl axis or germ (Anders, 2013).

Carrot (Dacus carota) is the most important crop of Apiaceae family. It is a root vegetable that has worldwide distribution. They were first used for medical purposes and gradually used as food. Written records in Europe indicated that they were cultivated prior to the tenth century. The colours of carrot flesh may be white, yellow, orange, red, purple, or very dark purple (Joao, 2014). They are an excellent source of antioxidant compounds, and the richest vegetable source of the pro-vitamin A carotenes. Carrots' antioxidant compounds help protect against cardiovascular disease and cancer and also promote good vision, especially night vision. They have a unique combination of three flavonoids: kaempferol, quercetin and luteolin (Lila, 2004). They are also rich in other phenols (Gonçalves, Pinheiro, Abreu \&Silva, 2010).

Complementary foods are foods other than breast milk or infant formula (liquids, semisolids, and solids) introduced to an infant to provide nutrients (USDA, 2009). Complementary foods are mostly produced from food which include, cereals, such as wheat, maize and rice, roots, tuber, legumes such as soybeans, cowpeas etc. Formulation of complementary foods can be made by using one or combination of more than one plant product (cereal such as maize, millet and sorghum combined with legume such as cowpea, groundnut, soybeans etc) (Akpapunam \& Dedeh, 1995).

Complementary foods are expected to be high in energy density, containing all essential amino acids, required vitamins and minerals and safe level of antinutritional components while retaining the qualities for palatability (Abeshu, Lelisa, \& Geleta, 2016). Animal-source foods such as milk are important for complementary feeding as they provide high quality protein, bioavailable micronutrients, and have low levels of anti-nutrients and fibre. However, these are unaffordable for majority of the population in sub-Saharan African countries like Nigeria. Most nursing mothers use local alternatives to milk which include cereals such as maize or millet in combination with legumes such as soybean and groundnut. Cereals that are commonly used in the preparation of infant complementary food are limiting in lysine and methionine which can be supplemented by the addition of legume such as soybean. The gelatinization of starch is associated with the disruption of granular structure causing starch molecules to dissolve in water and many food products contain partially cooked starch granules that contribute to their functional and structural properties (Ratnayake \& Jackson, 2006). Pre-gelatinization will result in partially cooked starch which can enhance the functional quality of the complementary food. Germination with its earlier stated advantages can also enhance the quality of complementary foods. Hence adequate processing and judicious blending of locally available foods could result in improved intake of nutrients. This studied was therefore, aimed at the production and evaluation of the proximate and sensory properties of complementary food from 
pre-gelatinised malted maize, soy and carrot.

\section{Method}

\subsection{Preparation of Malted Pre-Gelatinized Maize, Soybean and Carrot Flour}

Yellow variety of maize (Zea mays), soybean (Glycine max) and carrot (Dacus carota) were bought from a local market (Mile 3) in Diobu, Port Harcourt, Rivers State, Nigeria.

Five kilograms of sorted and washed maize were spread on jute bags and allowed to sprout at room temperature. The sprouts were removed, the grains washed and boiled with 4 litres of water until tender and easily crushed between the thumb and index finger. Excess water was drained out of the boiled maize and the malted pre-gellatinized grains were dried in a hot oven at $60^{\circ} \mathrm{C}$ overnight. The dried grains were milled with a hammer mill and sieved to obtain the malted pre-gellatinized maize flour (M). The flour was packaged in a transparent plastic container with lid and stored in the deep freezer until required for use.

The soy and carrot flour were prepared as described by Barber, Obinna-Echem \& Ogburia (2017). Briefly, $3 \mathrm{~kg}$ of sorted and washed soybeans were blanched at $85^{\circ} \mathrm{C}$ for 2 minutes, and then soaked in $6 \mathrm{~L}$ of water for $24 \mathrm{~h}$ with a change of water after every $6 \mathrm{~h}$. The soybean seed testae were removed, the seeds washed and dried in a cabinet at $50^{\circ} \mathrm{C}$ for $24 \mathrm{~h}$. The product was milled with hammer mill and sieved to obtain the fermented soy flour (S). Fresh carrots were washed and the outer layers scraped. About $3 \mathrm{~kg}$ of the carrot were grated, dried at $50^{\circ} \mathrm{C}$ for $8 \mathrm{~h}$ and blended with hammer mill to obtain carrot flour $(\mathrm{C})$. The prepared flours were packaged separately in well labelled plastic containers and preserved in a deep freezer until required for use.

\subsection{Recipe Formulation for the Malted Pre-Gelatinized Maize, Soybean and Carrot (MSC) Complementary Food}

The malted and pre-gelatinized maize flour was supplemented with different proportions of the soybeans and carrot flour as shown in Table 1. To obtained a homogenous flour, the different combinations were individually homogenized in a rotary mixer (Philips, type HR 1500/A, Holland), and then stored in airtight plastic containers and preserved in a deep freezer until required for analyses. Malted and pre-gelatinized maize flour without any substitution served control.

Table 1. Recipe (in grams) for the formulation of malted and pre-gelatinized maize-soybean-carrot complementary food

\begin{tabular}{cccc}
\hline \multirow{2}{*}{ Sample ID } & Malted and pre-gelatinized & \multicolumn{2}{c}{ Levels of Substitution } \\
\cline { 3 - 4 } maize flour (M) & 80.000 & 20.000 & Soybean Flour (S) \\
\hline & 73.125 & 23.125 & Carrot Flour (C) \\
\hline A & 66.250 & 26.250 & 3.750 \\
B & 65.625 & 23.125 & 7.500 \\
C & 65.000 & 20.000 & 11.25 \\
D & 63.125 & 33.125 & 15.000 \\
E & 63.125 & 25.625 & 3.750 \\
F & 60.000 & 25.000 & 11.250 \\
G & 100 & 0 & 15.000 \\
H & & & 0 \\
I & & & \\
\hline
\end{tabular}

\subsection{Proximate Analysis}

Proximate analyses were carried out on the samples using standard AOAC (2005) methods. Moisture content was calculated after drying at $105^{\circ} \mathrm{C}$ to constant weight in an air oven (Thermo Scientific-UT 6200, Germany). Lipids were estimated by exhaustive extraction of known weight of samples with petroleum ether using rapid Soxhlet extraction apparatus (Gerhardt Soxtherm SE- 416, Germany). Determination of protein was by Kjeldahl method. The efficiency of the nitrogen values were corrected with acetanilide values and multiplied by the factor of 6.25 to obtain the protein value. Ash was determined gravimetrically after incineration in a muffle furnace (Carbolite AAF-11/18, UK) for $24 \mathrm{~h}$ at $550^{\circ} \mathrm{C}$. Crude fibre was obtained by difference after the incineration of the ash-less filter paper containing the insoluble materials from the hydrolysis and washing of moisture free defatted sample $(0.5 \mathrm{~g})$. Carbohydrate content was determined by the difference: $100 \%$ - (\% MC + \% Ash + \% Crude protein $+\%$ Fat $+\%$ Crude fibre). Energy $(\mathrm{Kcal} / \mathrm{g})$ was calculated using the Atwater factor of $4.0 \mathrm{Kcal} / \mathrm{g}$ for protein and carbohydrate and $9 \mathrm{Kcal} / \mathrm{g}$ for fat. 


\subsection{Sensory Analysis of the Malted and Pre-Gelatinized Maize, Soybean and Carrot (MSC) Complementary Porridge}

Each of the various blends as shown in Table 1 was mixed with $200 \mathrm{~mL}$ of cold water to make slurry. Then equal part of boiling water was added to the slurry with continuous stirring to obtain the Malted and pre-gelatinized Maize-Soybean-Carrot (MSC) porridge. Sensory properties (colour, mouth-feel, taste, texture and overall acceptability) of the porridge pap from different soybean and carrot substitutions were carried out using a panel of 20 assessors consisting of nursing mothers, staff and students of the Department of Food Science and Technology, River State University, Port Harcourt. The assessors are regular consumers of fermented maize porridges. Mothers were preferred to infants as the mothers are the ones that make choices of what complementary food to feed their infants with. The aroma, colour, taste, texture and overall acceptability of the samples were evaluated in sensory evaluation boots where coded porridge samples were presented in random order with a ballot sheet for each sample. The scores were based on a 9 - point hedonic scale, with the degree of likeness of the product attribute expressed as: 1 - dislike extremely, 2 - dislike very much, 3 - dislike moderately, 4 - dislike slightly, 5 - neither like nor dislike, 6 - like slightly, 7 - like moderately, 8 - like very much and 9 - like extremely. Assessors were instructed to score colour first and water was provided for rinsing the mouth. Expectoration cups with lids were provided for panelists who did not wish to swallow the samples.

\subsection{Statistical Analysis}

Results were analyzed statistically by analysis of variance and difference between means separated using the Least Significance Difference (LSD) procedure. The non-parametric Friedman test and 2-sample t-test were employed in determining the statistical differences among the product sensory attributes.

\section{Results and Discussion}

\subsection{Proximate Composition of Maize, Soybean and Carrot (MSC) Complementary food}

The proximate compositions of the porridges are shown in Table 2. The moisture content of the samples varied significantly ( $\mathrm{P} \leq 0.5$ ) from 8.10 for sample $\mathrm{H}$ to $3.55 \%$ for Sample I (Control without soybean and carrot). There was increase in the moisture content with the addition of soy and carrot flour. The moisture contents of the samples were within the acceptable limit of not more than $10 \%$ for long term storage of flour. Low moisture content would prevent the growth of mould and reduce moisture dependant biochemical reactions (Onimawo \& Akubor, 2012).

The protein content of the samples increased $(\mathrm{P} \leq 0.5)$ with the increase in soy and carrot substitution. Sample $\mathrm{F}$ had significantly $(\mathrm{P} \leq 0.5)$ the highest protein content of $21.53 \%$ while the control had significantly $(\mathrm{P} \leq 0.5)$ the lowest protein content of $11.61 \%$. The increase in protein could be attributed to the soy flour. Maize is limiting in lysine and tryptophan. It is expected that the amino acid of soybean will complement that of cereal flour. The protein is important for tissue replacement, disposition of lean body mass and growth. Fat is important in the diets of infants and young children as it provides essential fatty acids, facilitates absorption of fat soluble vitamins, enhances dietary energy density and sensory qualities and the prevention of undesirable weight gain in infants. The fat content of the blends ranged from 10.86 to $1.68 \%$ for Sample F and A respectively. Fat is important in the diet of infant and young children because it provides essential fatty acid, facilitates absorption of fat soluble vitamin, enhance dietary energy, density and sensory quality (FAO 2001). It has been recommended that, during the complementary feeding period (6-12 months) a child's diet should derive $30-40 \%$ of energy from fat (Michaelsen Weaver, Branca, \& Robertson, 2000). According to a joint WHO/FAO/UNU The energy requirements for a 6-month-old female involved in moderate physical activity is $340 \mathrm{~kJ} \mathrm{~kg}^{-1}$ body weight (WHO, 2007), an infant weighing $7.34 \mathrm{~kg}$ would $2495 \mathrm{~kJ}$ of energy daily. The fat composition of this complementary food will only meet $2.5-16.4 \%$ of the energy requirement. This however can be enhanced with available oil to increase the recommended fat ratio. The samples had varying ash content from $2.8-1.45 \%$ for sample $\mathrm{C}$ and $\mathrm{G}$ respectively. The general trend was that of an increase with increase in soy flour substitution. Ash is an indication of availability of minerals.

The crude fibre content was low and ranged between 4.40 and 0.20 for sample $\mathrm{F}$ and $\mathrm{B}$ respectively. This range is within the fibre content reported for maize, soy bean, and carrot (Arawande \& Borokini, 2010; Butt \& Batool 2010). Fibre plays a role in the increased the utilization of nitrogen and absorption of some other micronutrients. The low fibre content is in agreement with the report that food used for complementary feeding should contain low fibre as high fibre can lead to high water absorption and displacement of nutrient and energy needed for the growth of children less than two years (Klim, Isaac \& Joseph 2001; Michaelsen, Weaver, Branca \& Robertson, 2000). 
The carbohydrate content of the samples varied significantly $(\mathrm{P} \leq 0.5)$. The control $(100 \%$ maize flour $)$ had significantly $(\mathrm{P} \leq 0.5)$ the highest carbohydrate content of $75.61 \%$. The carbohydrate content for the malted and pre-gelatinized maize, soybean and carrot flour blends ranged between 55.30 and $71.60 \%$ for sample B and sample I, respectively. Maize is mostly a carbohydrate food hence it was out of place for the unsubstituded sample to have high carbohydrate content compared to others. The energy value in the formulation varied $(\mathrm{P} \leq$ $0.5)$ due to variation in protein and fat contents of the samples. The values varied between360.43 - 405.00 $\mathrm{Kcal} / \mathrm{g}$.

Table 2. Proximate Composition (\%) of malted and pre-gelatinized maize, soy and carrot flour blend

\begin{tabular}{cccccccc}
\hline Samples & Moisture & Ash & Fat & Protein* & $\begin{array}{c}\text { Crude } \\
\text { Fibre }\end{array}$ & Carbohydrate & $\begin{array}{c}\text { Energy } \\
(\mathrm{kcal} / \mathrm{g})\end{array}$ \\
\hline $\mathbf{A}$ & $6.85 \pm 0.10^{\mathrm{b}}$ & $1.90 \pm 0.50^{\mathrm{ab}}$ & $1.68 \pm 0.50^{\mathrm{f}}$ & $19.15 \pm 0.05$ & $3.24 \pm 0.10^{\mathrm{b}}$ & $67.19 \pm 1.04^{\mathrm{c}}$ & $360.43 \pm 0.50^{\mathrm{d}}$ \\
$\mathbf{B}$ & $5.77 \pm 0.13^{\mathrm{c}}$ & $2.59 \pm 0.90^{\mathrm{ab}}$ & $4.93 \pm 0.19^{\mathrm{de}}$ & $15.48 \pm 0.00$ & $0.20 \pm 0.00^{\mathrm{e}}$ & $71.06 \pm 0.84^{\mathrm{b}}$ & $390.44 \pm 5.01^{\mathrm{b}}$ \\
$\mathbf{C}$ & $6.00 \pm 0.00^{\mathrm{c}}$ & $2.80 \pm 1.10^{\mathrm{a}}$ & $8.13 \pm 0.33^{\mathrm{b}}$ & $18.29 \pm 0.05$ & $2.40 \pm 0.40^{\mathrm{c}}$ & $62.39 \pm 1.23^{\mathrm{d}}$ & $395.83 \pm 7.63^{\mathrm{a}}$ \\
$\mathbf{D}$ & $6.97 \pm 0.38^{\mathrm{b}}$ & $2.35 \pm 0.05^{\mathrm{ab}}$ & $5.22 \pm 0.68^{\mathrm{cde}}$ & $19.54 \pm 0.01$ & $3.28 \pm 0.14^{\mathrm{b}}$ & $62.66 \pm 0.88^{\mathrm{d}}$ & $375.71 \pm 2.61^{\mathrm{c}}$ \\
$\mathbf{E}$ & $6.12 \pm 0.12^{\mathrm{bc}}$ & $2.15 \pm 0.25^{\mathrm{ab}}$ & $2.55 \pm 0.00^{\mathrm{f}}$ & $17.26 \pm 0.02$ & $1.40 \pm 0.01^{\mathrm{d}}$ & $70.53 \pm 0.38^{\mathrm{b}}$ & $374.10 \pm 1.40^{\mathrm{c}}$ \\
$\mathbf{F}$ & $6.12 \pm 0.12^{\mathrm{bc}}$ & $1.80 \pm 0.00^{\mathrm{ab}}$ & $10.86 \pm 1.77^{\mathrm{a}}$ & $21.53 \pm 0.00$ & $4.40 \pm 0.15^{\mathrm{a}}$ & $55.30 \pm 2.03^{\mathrm{e}}$ & $405.00 \pm 7.76^{\mathrm{a}}$ \\
$\mathbf{G}$ & $7.48 \pm 0.62^{\mathrm{a}}$ & $1.45 \pm 0.06^{\mathrm{b}}$ & $7.34 \pm 0.07^{\mathrm{bc}}$ & $17.83 \pm 0.00$ & $1.48 \pm 0.29^{\mathrm{d}}$ & $64.44 \pm 0.34^{\mathrm{cd}}$ & $395.07 \pm 0.77^{\mathrm{ab}}$ \\
$\mathbf{H}$ & $8.10 \pm 0.00^{\mathrm{a}}$ & $1.99 \pm 0.10^{\mathrm{ab}}$ & $6.60 \pm 0.51^{\mathrm{bcd}}$ & $18.01 \pm 0.01$ & $1.08 \pm 0.10^{\mathrm{d}}$ & $64.23 \pm 0.50^{\mathrm{d}}$ & $388.28 \pm 2.53^{\mathrm{b}}$ \\
$\mathbf{I}$ & $3.55 \pm 0.05^{\mathrm{d}}$ & $2.40 \pm 0.10^{\mathrm{ab}}$ & $3.67 \pm 0.49^{\mathrm{ef}}$ & $11.61 \pm 0.00$ & $3.17 \pm 0.19^{\mathrm{b}}$ & $75.61 \pm 0.63^{\mathrm{a}}$ & $381.85 \pm 1.86^{\mathrm{bc}}$ \\
\hline
\end{tabular}

Values with same superscript in the same column do not differ significantly $(\mathrm{p} \leq 0.05)$. $\mathrm{N}=3 \pm \mathrm{SD}$.

*Protein content of the samples varied significantly $(\mathrm{p} \leq 0.05)$.

Blend (M:S:C); M = Malted pre-gelatinized maize flour, S = Soy flour, C = Carrot flour. A (80: 20: 0), B (73.125: 23.125: 3.75), C (66.250: 26.250: 7.50), D (65.625: 23.125:11.25), E (65: 20:15), F (63.125: 33.125: 3.75), G (63.125:25.625: 11.25), H (60: 25: 15) and I (100:0:0)

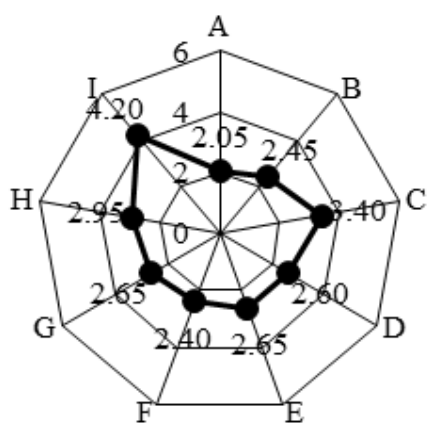

Aroma

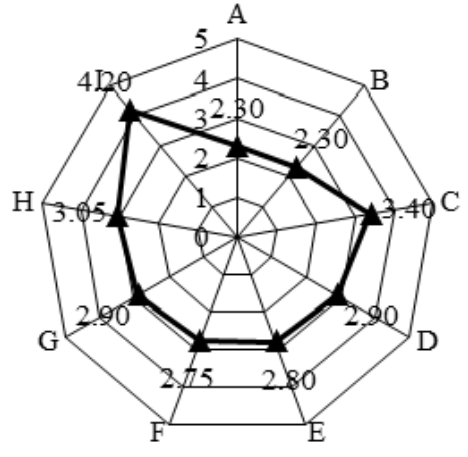

Texture

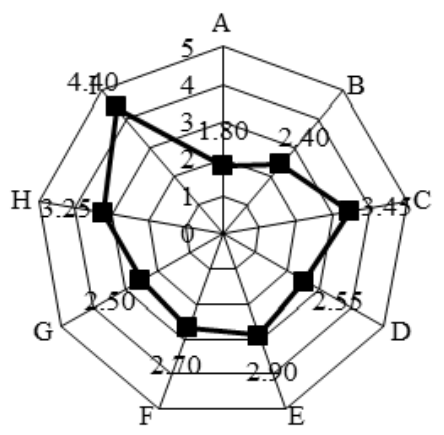

Taste

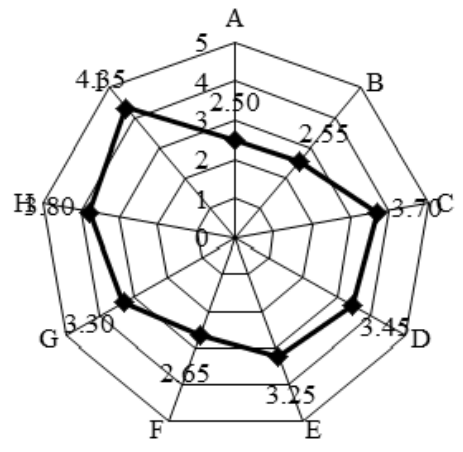

Colour

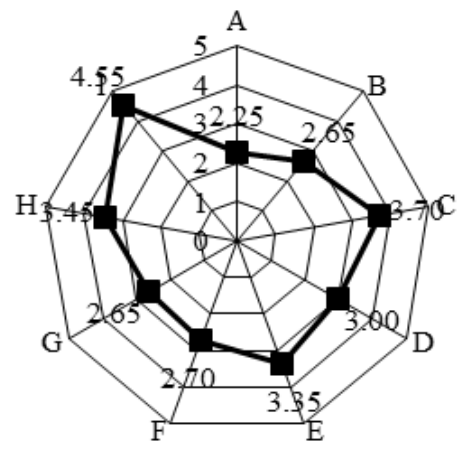

General Acceptatbility

Figure 1. Sensory analysis of porridges from malted and pre-gelatinized maize, soy and carrot blend Blend (M:S:C); $\mathrm{M}=$ Malted pre-gelatinized maize flour, $\mathrm{S}=$ Soy flour, $\mathrm{C}=$ Carrot flour A (80: 20: 0), B (73.125: 23.125: 3.75), C (66.250: 26.250: 7.50), D (65.625: 23.125:11.25), E (65: 20:15), F (63.125: 33.125: 3.75), G (63.125:25.625: 11.25), H (60: 25: 15) and I (100:0:0). 
Generally, the substitution with soybeans and carrot flours increased the nutrient composition of the malted pre-gelatinized maize, soybean and carrot flour blends. Particularly the soy flour as sample $\mathrm{F}$ with the highest soy flour substitution $(33.123 \mathrm{~g})$ had significantly $(\mathrm{P} \leq 0.5)$ the highest protein $(21.53 \%)$, fat $(10.86 \%)$ and energy $(405 \mathrm{Kcal} / \mathrm{g})$ values. According to a Joint WHO/FAO/UNU Expert Consultation report (WHO, 2007) the daily protein and energy requirements for a 6-month-old female involved in moderate physical activity are $1.12 \mathrm{~g}$ $\mathrm{kg}^{-1}$ and $340 \mathrm{~kJ} \mathrm{~kg}^{-1}$ body weight, respectively; therefore an infant weighing $7.34 \mathrm{~kg}$ would require $8.2 \mathrm{~g}$ of protein and $2495 \mathrm{~kJ}$ of energy daily. The consumption of $100 \mathrm{~g}$ of the porridges would meet more than $100 \%$ (189 - 263\%) of the daily protein requirement, while the energy requirement would be met with the consumption of $147-166 \mathrm{~g}$ of the porridge.

\subsection{Sensory Evaluation}

There were significant differences $(\mathrm{P} \leq 0.5)$ among the sample in colour, texture, taste, aroma and general acceptability (Figure. 1). The control sample without any substitution had significantly $(\mathrm{P} \leq 0.5)$ the highest score $(\geq 4.20)$ for all the attributes, while sample A had the least $(\leq 1.80)$. The assessors' range of likeness for all the attributes were within dislike very much and neither like nor dislike. This could be attributed to the malting effect of the maize. The colour of the porridges may also have been affected by the addition of carrot. Although colour is less important for babies, mothers would play a vital role for any complementary food to be successfully utilized and accepted. The porridge from Sample F had a beany flavor as described by the panellists. This sample F had the highest soy flour substitution and the flavour could be attributable to the beany flavor of soybean. On the basis of nutrient composition, sample F could be recommended, while the sensory properties particularly the taste and flavour can be improved with the addition of sugar.

\section{Conclusion}

Maize, soybean and carrot are locally available and affordable raw materials that can be used by mothers as home-based complementary foods. There was increase in the nutrient content of the blends formulated in this study, particularly sample $\mathrm{F}$ with the highest soy flour substitution $(33.123 \mathrm{~g})$ that had significantly the highest protein $(21.53 \%)$, fat $(10.86 \%)$ and energy $(405 \mathrm{Kcal} / \mathrm{g})$ values. This would be recommended for good quality porridge. The sensory analysis revealed the need for further investigation as to enhance the overall acceptability of the product.

\section{Acknowledgments}

The author acknowledges the technical assistance of Mr Friday Owuno from the Analytical Unit of Food Science and Technology Laboratories, Rivers State University, Nkpolu-Oroworokwu, Port Harcourt, Rivers State Nigeria.

\section{References}

Abeshu, M. A., Lelisa, A., \& Geleta, B. (2016). Complementary Feeding: Review of Recommendations, Feeding Practices, and Adequacy of Homemade Complementary Food Preparations in Developing Countries Lessons from Ethiopia. Frontiers in Nutrition, 3(41), 1-9. https://doi.org/10.3389/fnut.2016.00041

Addo-Quaye, A. A., Darkwa, A. A., \& Ampiah, M. K. P. (2011). Performance of three cowpea (Vigna unguiculata $(L)$ Walp) varieties in two agro-ecological zones of the Central Region of Ghana I: Dry matter production and growth analysis. ARPN Journal of Agricultural and Biological Science, 6(2), 1-9.

Afify AE-M. M. R., El-Beltagi, H. S., Abd El-Salam, S. M., \& Omran, A. A. (2012). Protein Solubility, Digestibility and Fractionation after Germination of Sorghum Varieties. PLOS ONE, 7(2), e31154. https://doi.org/10.1371/journal.pone.0031154

Akpapunam, M. A., \& Dedeh, S. (2012). Traditional lactic acid fermentation maltaddition and quality development in maize-cowpea weaning blends. Food and Nutrition Bulletin, 16(1), 1075-1081.

Anders, K. (2013). Literature review on aspects of human consumption of soy. $\mathrm{PhD}$, Department of Food Science, University of Aarhus, Denmark.

AOAC (2005). Official methods of analysis of Association of Official Analytical Chemists International (18 ed.). Gaithersburg, Maryland, USA: AOAC International.

Arawande, J. O., \& Borokini, F. B. (2010). Comparative study on chemical composition and functional properties of three nigerian legumes (jack beans, pigeon pea and cowpea). Journal of Emerging Trends in Engineering and Applied Sciences (JETEAS), 1(1), 89-95.

Barber, L. I., Obinna-Echem, P. C., \& Ogburia, E. M. (2017). Proximate composition micronutrient and sensory 
properties of complementary food formulated from fermented maize, soybeans and carrot flours. Sky Journal of Food Science, 6(3), 033 - 039. Available online http://www.skyjournals.org/SJFS

Butt, M. S., \& Batool, R. (2010). Nutritional and functional properties of some promising legumes protein. Isolates.Pakistin Journal of Nutrition, 9(4), 373-379. https://doi.org/10.3923/pjn.2010.373.379

Elyas, S. H. A., El Tinay, A. H., Yousif, N. E., \& Elsheikh, E. A. E. (2002). Effect of natural fermentation on nutritive value and in vitro protein digestibility of pearl millet. Food Chemistry, 78(1), 75-79. https://doi.org/10.1016/S0308-8146(01)00386-7

FAO (2001). Human nutrition and mineral requirement: Report of a Joint FAO/WHO Expert Consultation. Bangkok, Thailand. Food and Nutrition Division, FAO Rome.7-8.

FAO (2012). Maize in human nutrition. FAO Food and Nutrition Series, No. 25.ISBN 92-5-103013-8.

FAO (2014).Food and Agriculture Organization of the United Nations, Food Security Statistics.

Gonçalves, E. M., Pinheiro, J., Abreu, M., \& Silva, C. L. (2010). Carrot (Daucus carota L.) peroxidase inactivation, phenolic content and physical changes kinetics due to blanching. Journal of Food Engineering, 97, 574-581. https://doi.org/10.1016/j.jfoodeng.2009.12.005

Hornick, B. A., \& Weiss, L. (2011). Comparative nutrient analysis of commonly consumed vegetables: support for recommending a nutrition education approach emphasizing specific vegetables to improve nutrient intakes. Nutrition Today, 46(3), 130-137. https://doi.org/10.1097/NT.0b013e31821a82f3

Joao, C. S. D. (2014). Nutritional and health benefits of carrots and their seed extracts. Food and Nutrition Sciences, 5, 2147-2156. https://doi.org/10.4236/fns.2014.522227

Kalui, C. M., Mathara, J. M., \& Kutima, P. M. (2010). Probiotic potential of spontaneously fermented cereal based foods - A review. African Journal of Biotechnology, 9(17), 2490-2498.

Katina, K.., Liukkonen, K.-H., Kaukovirta-Norja, A., Adlercreutz, H., Heinonen, S.-M., Lampi, A.-M, Pihlava, J.-M., \& Poutanen, K. (2007). Fermentation-induced changes in the nutritional value of native or germinated rye. Journal of Cereal Science, 46(3), 348-355. https://doi.org/10.1016/j.jcs.2007.07.006

Klim, F., Isaac, O., \& Joseph, J. O. (2001). Feeding and nutrition and infant and young children. Energy and menonutrients: WHO European Series, 87, 45-80.

Lei, V., Friis, H., \& Michaelsen, K. F. (2006). Spontaneously fermented millet product as a natural probiotic treatment for diarrhoea in young children: An intervention study in Northern Ghana. International Journal of Food Microbiology, 110(3), 246-253. https://doi.org/10.1016/j.ijfoodmicro.2006.04.022

Lila, M. A. (2004). Anthocyanins and human health: An in vitro investigative approach. Journal of Biomedicine and Biotechnology, 2004(5), 306-313. http://dx.doi.org/10.1155/S111072430440401X

Michaelsen, K. F., Weaver, L., Branca, F., \& Robertson, A. (2000). Feeding and nutrition of infants and young children-Guidelines for the WHO European Region, with emphasis on the former Soviet countries. WHO Regional Publications, European Series, 87, 45-80

Moongngarm, A., \& Saetung, N. (2010). Comparison of chemical compositions and bioactive compounds of germinated rough rice and brown rice. Food Chemistry, 122, 782-788. https://doi.org/10.1016/j.foodchem.2010.03.053

Moongngarm, A., Moontree, T., Deedpinrum, P., \& Padton, K. (2014). Functional Properties of Brown Rice Flour as Affected by Germination. APCBEE Procedia, 8, 41-46. https://doi.org/10.1016/j.apcbee.2014.01.077

Obinna-Echem, P. C., Kuri, V., \& Beal, J. (2014). Evaluation of the microbial community, acidity and proximate composition of akamu, a fermented maize food. Journal of the Science of Food and Agriculture, 94(2), 331e340. http://dx.doi.org/10.1002/jsfa.6264.

Okoh, N. (2014). Functional properties of defatted flour and protein isolate of fluted pumpkin seed flours. Nigerian Journal of Chemistry, 216-226.

Omimawo, I., \& A, Akubor, P. I. ( 2012). Food Chemistry (Integrated Approach with Biochemcial background). $2^{\text {nd }}$ edn. Joytal printing press, Agbowo, Ibadan, Nigeria.

Ratnayake, W. S., \& Jackson, D. S. (2006). Gelatinization and solubility of corn starch during heating in excess water: new insights. Journal of Agricultural and Food Chemistry, 54(10), 3712-3716.

https://doi.org/10.1021/jf0529114 
Shimelis, E. A., \& Rakshit, S. K. (2007). Effect of processing on antinutrients and in vitro protein digestibility of kidney bean (Phaseolus vulgaris L.) varieties grown in East Afric. Food Chemistry, 103(1), 161-172. https://doi.org/10.1016/j.foodchem.2006.08.005

Subba Rao, M. V. S. S. T., \& Muralikrishna, G. (2002). Evaluation of the Antioxidant Properties of Free and Bound Phenolic Acids from Native and Malted Finger Millet (Ragi, Eleusine coracana Indaf-15). Journal of Agricultural and Food Chemistry, 50(4), 889-892. https://doi.org/10.1021/jf011210d

Towo, E., Matuschek, E., \& Svanberg, U. (2006). Fermentation and enzyme treatment of tannin sorghum gruels: effects on phenolic compounds, phytate and in vitro accessible iron. Food Chemistry, 94(3), 369-376. https://doi.org/10.1016/j.foodchem.2004.11.027

USDA, (2009). Infant Nutrition and Feeding: A guide for use in WIC and CSF programs. United State Department of Agriculture Food and Nutrition Service: Special supplemental Nutrition Program for Women Infants and Children (WIC)

https://wicworks.fns.usda.gov/wicworks/Topics/FG/Chapter5_ComplementaryFoods.pdf

WHO, (2007). Protein and amino acid requirements in human nutrition: report of a Joint FAO/WHO/UNU Expert Consultation. WHO Technical Report Series No. 935, Geneva, Switzerland, p. 88.

\section{Copyrights}

Copyright for this article is retained by the author(s), with first publication rights granted to the journal.

This is an open-access article distributed under the terms and conditions of the Creative Commons Attribution license (http://creativecommons.org/licenses/by/4.0/). 